\title{
Analysis on the Use of Red Independent Cultural Resources to Enhance the Probity Education of College Students
}

\author{
Sasa $\mathrm{Li}^{1}$ \\ ${ }^{1}$ Yulin College, Yu Lin, Shanxi, 719000
}

Keywords: Red Independent cultural resources; College Students; Probity Education

\begin{abstract}
Red independent cultural resources are the material resources and non-material resources which the CPC led the Chinese people of all nationalities created and formed in the long-term drive and arduous revolutionary struggle and socialist modernization construction. Red independent cultural resources can not only provide vivid case of material integrity education and a broad base of practical education for college students, but also support and expand education carriers and forms of education for probity education of college students.
\end{abstract}

\section{Introduction}

CPC eighteen states: "against corruption and building clean politics, the party has consistently adhered to the distinctive political position, is a major political problem concerns the people to solve this problem properly, it will cause fatal damage to the party, even the country." Red Independent cultural resources is the party led the people in revolution, construction and reform and opening up in different historical periods bred from the clean system, Independent spirit and its carrier, it contains both historical periods have different values of integrity and meaning, with stirring warning educational role, but also provide an inexhaustible case material and broad education base for university students practice honest education [1].

\section{The Great Value of Red Independent Cultural Resources in Probity Education of College Students}

Red Independent Cultural Resources Provided Fresh, Vivid Case Material in Probity Education for University Students. Integrity is the party's fine revolutionary tradition. Early in Jinggangshan base, Mao Zedong, Zhu De and the Red Army soldiers to eat red rice and pumpkin soup, wear sandals, wear sackcloth, 5 cents per person per day for meals. In the Central Soviet Area, 1933 Mao Zedong issued "on punishing acts of corruption and waste precepts," the entire Soviet launched a massive anti-corruption struggle, and dealt with a number of corruption cases. Mao led wearing patched clothes, Zhu made with horse hair brush, Lin Boqu wearing a leg with a rope wrapped around glasses.

Red Independent Cultural Resources Provided and Expand the Education Carrier and Forms of Probity Education for University Students. Universities can actively explore the school, local red integrity and cultural resources to create a rich cultural atmosphere of the campus clean. Sichuan, Shaanxi universities give full play to the local red Against cultural resources, organize the students to "re-take the red Road, reliving one party oath, quartet red songs" and other activities; Chongqing, Hunan, Jiangxi Universities and other places of education through the organization of university student apartment honest speech contests, theatrical performances, blackboard newspaper exhibition, exhibition and other forms of corruption in red campus culture activities, effectively promoted the development of college students honesty education [2].

Red Independent Cultural Resources Provided Practical Education Base for College Students Probity Education. Universities are distributed at each location key cultural relics protection units at all levels of the revolution, patriotism education base, and many of the material aspects, spiritual red cultural resources. As the revolutionary war, Southeast had staged Hunan, Hubei, Sichuan and Guizhou Long led the Red Army to create a revolutionary base, the Second and Sixth Army victory reunion here, Liu and Deng XiuShanXian liberation through here, started the 
People's Liberation Army liberation campaign Southwest and other scenes of historical drama, was left a rich and valuable cultural resources red integrity, probity education for university students to carry out provides a very rare practice education base. Universities should give full play to the base warning college students clean the prevention function

\section{The Base Path of Red Independent Cultural Resources Being Used in College Students' Integrity Education.}

Build Red Independent Cultural Communication Platform and Make Honest Education into Campus Culture Construction. Schools can take advantage of a variety of media to build a school campus culture Communications Platform Independent red, full red alert in corruption cases resource integrity in the educational role of the honest education into the campus culture construction: First, open the newspaper magazine "Red Independent" column, dig, advocacy of revolution, construction and reform period, China clean typical story, stories, hire experts, the Independent Commission Against cultural connotation of red scholar, essence, function and other related issues to interpret, to enhance awareness of Students Against ; the second is the development of the organization Students Against use red and cultural resources, cultural integrity red writing books, articles, creative red Independent literary works, the Independent Commission Against cultural theater and acted in red, sing red songs corruption, efforts to create a number of educational, readable wins, Against strong red ornamental cultural works; third is to play the advantages of the campus network, campus network open "Red Independent Culture", "Independent cinema", "alarm bells ringing" and other columns, describes the different historical periods honest characters, stories, proverbs , epigram.

Exploitation Red Independent Cultural Resources and Make Integrity Education into Teaching Materials, Classrooms and Teaching Disciplines. First it's the textbooks. Independent cultural resources throughout the red parts of the country, universities should take advantage of these resources to prepare for college students honesty education materials used and applied to teaching. Second it's the classroom. One is the development and utilization of Chinese Communist Party in the red-corruption education resources and incorporate SCHOOL classroom teaching and training among the student leaders, prepare party members and party activists were honest education. The second is the development and utilization of revolution, construction and reform period, Chinese red and incorporated in the Independent Commission Against cultural resources of ideological and political theory courses and "Situation and Policy" Teaching Students among the students honest education. Third disciplines into teaching [3].

Broaden Red Integrity Culture Popular Channel and Make Honest Education into Students' Extracurricular Activities. First is organizing Red Independent Cultural Awareness Month activities. The second is to carry out the Independent Commission Against cultural resources to visit the red activities. Integrity Education "is a hands-on experience as the basic way to make educated in the practice experience, spiritual resonance, thus effectively within the external educational content into their own ideological and moral quality, achieve moral realm of sublimation. Third, to conduct study and analysis Typical red Against Corruption in University Case activities. Schools can convene special report honest, the founder of "clean" bulletin boards, newsletters and other forms.

\section{The Basic Principles of Red Independent Cultural Resources Being Used in College Students' Integrity Education.}

Scientific Principles. Development and utilization of cultural resources for the Students Independent Red Integrity Education provides fresh and vivid case material, educational support and education base, broaden the honest educational way. But the development and utilization of cultural resources to carry out the Independent Commission Independent Red honest education should adhere to scientific principles. Independent cultural communication in the red platform to build and broaden the popular red integrity culture channel, so honest education into schools, before 
entering class internal and external activities, must be on the red Independent cultural resources for in-depth and meticulous research, the development of scientific development and utilization of a specific plan [4].

Typical Principle. That is a positive typical banner is the mirror opposite of the typical. Teachers use red when the Independent Commission Against cultural resources to carry out integrity education, to follow the typical principle, to choose those with representative and typical red integrity and cultural resources and clean case, or use the TV, projectors, multimedia players, or vivid language, or through theatrical performances, etc. These resources, cases presented. The selection of resources, should seize the key, selection key to the point, and affect the overall situation. Screening is the focus of the revolution, construction and reform period, China honest banner-type character, typical events [5].

Innovation Principle. Teachers use the Red resources to carry out the Independent Commission Against cultural integrity education should adhere to the principle of innovation SUI: a red integrity and cultural resources to be innovative expressions and communication carriers. To continue to dig, extract red integrity and cultural resources and transformation, sublimation, artistry, appreciation of resources implies ideological, educational and its performance on the combine innovation resources manifestations; to the existing campus sites, newspaper spread of vector-based magazine, blackboard, etc., give full play to the advantages of network communication carriers, television, literary works, etc., to broaden the use of red Independent cultural resources to carry out integrity education channels. Second, we must use the red Independent innovation and cultural resources of ways and means to carry out integrity education.

\section{Conclusion}

Red independent cultural resources are the material resources and non-material resources which the CPC led the Chinese people of all nationalities created and formed in the long-term drive and arduous revolutionary struggle and socialist modernization construction. Red embodies integrity and cultural resources with Comrade Mao Zedong as the representative of the older generation of proletarian revolutionaries to overthrow imperialism, feudalism and bureaucrat-capitalism of hard course, this valuable material and spiritual wealth of quality resources become honest education of college students should be rational development, vigorously by the action of the independent commission independent cultural resources of this red honesty education in college students.

\section{Acknowledgements}

Project Name: Yulin Anti-Corruption Research Center Project, LZ-10.

\section{References}

[1] J. You. Current Colleges and Universities Strengthening Independent Cultural Construction. Chinese Higher Education, 2009 (18):12-21.

[2] P. Kang. Red Resources Development and the Socialist Core Value Education System. Morality and Civilization. 2008 (1):59-63.

[3] Y. Wang. The Use of Red Resources in This Ideological and Moral Education. Party Building (Academic Edition), 2005 (2):42-50.

4] H. Peng. Utilizing Resources in Jiangxi Red Culture Cultivating Students' National Spirit. South Metallurgy College, 2003(6):99-103.

[5] W. Dai. Red Resource Development. Jinggangshan University (Philosophy and Social Sciences), 2009 (03):55-63. 